\title{
Changes in size at maturity of European hake Atlantic populations in relation with stock structure and environmental regimes
}

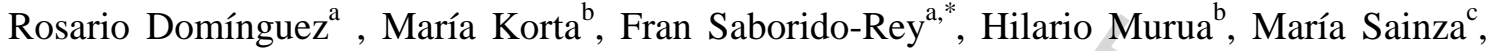 \\ Carmen Piñeiro ${ }^{\mathrm{c}}$ \\ ${ }^{a}$ Instituto de Investigaciones Marinas (CSIC), Eduardo Cabello, 6. 36208 Vigo, Spain \\ ${ }^{\mathrm{b}}$ AZTI Fundazioa, Portualde, Herrera Kaia z/g, 20110 Pasaia, Spain \\ ${ }^{\mathrm{c}}$ Instituto Español de Oceanografía, Cabo Estai - Canido. 36200 Vigo, Spain
}

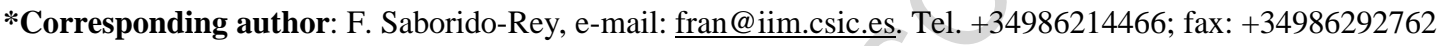

E-mail addresses: rosario@iim.csic.es (R. Dominguez), mkorta@pas.azti.es (M. Korta), hmurua@pas.azti.es (H. Murua), maria.sainza@vi.ieo.es (M. Sainza), carmen.pineiro@vi.ieo.es (C. Piñeiro)

\begin{abstract}
European hake (Merluccius merluccius) female size at maturity is estimated on an annual basis for Bay of Biscay and Galician coast, which are parts of the distribution of the Northern and Southern stocks, respectively. Clear trends in this reproductive parameter are observed along the time series and the potential factors affecting these trends have been investigated. Total biomass, different indexes of SSB, age diversity index, fishing mortality at age, NAO winter index, upwelling index and temperature were included in multiple regressions models to assess the relative importance of each of them on shifts in size at maturity.

Bay of Biscay and Galician coast hake have followed different evolution in patterns of changes in size at maturity. In Bay of Biscay, a steadily decline of $15 \mathrm{~cm}$ has been observed from 1987 to 2004, which is well predicted by fishing mortality and age diversity, but also the environment may have played an important role. However, on the Galician coast a drastic decline of $16 \mathrm{~cm}$ from 1980 to 1988 was followed by a rapid increase in size at maturity during the next 10 years to original values and a stable period in the last 6 years. Decreasing biomass may explain the decline in size at maturity in the first period. However, total biomass and spawning biomass declined even during the period when size at maturity increased, which is contrary to compensatory theory. Shifts in environmental regime, NAO and upwelling, may have contributed to a decelerated growth during this period that might explain the later maturation.
\end{abstract}

\section{Keywords}

Size at sexual maturity, Population structure, Environmental effects, Gadoid fisheries, Hake, Merluccius merluccius, Bay of Biscay, Galician Coast

\section{Introduction}

One of the basic goals of fisheries management is to conserve sufficient reproductive potential in a stock to allow for sustainable exploitation. To achieve this, most of the stocks are managed based on maintaining certain levels or limit thresholds of Spawning Stock Biomass 
(SSB) on the assumption this is an indicator of the 'viability' of the stock. Therefore assessment and management of fish populations currently rely on correct estimation of the SSB (Hilborn and Walters, 1992), which is based on accurate maturity ogives of the population. Those ogives are usually calculated from a macroscopic evaluation of the gonad maturity. However, macroscopic analysis may overestimate the proportion of mature females (Murua et al., 2003; Vitale et al., 2006).. Moreover, in most scientific assessments of European marine fish stocks, SSB is calculated using a fixed maturity ogive, ignoring the inter-annual variability in this parameter.

Most of the European marine fish resources are outside safe biological limits or overexploited. In spite of the several technical measures taken to recover the stock status, most have failed. This has raised again the debate (Anon., 2004) as to whether fishing is the main factor causing the decline of stocks, or whether environmental factors are the main cause (Cook and Heath, 2005). To demonstrate that environment plays important role on population dynamics is a hard task, firstly because its effect is often mixed with those produced by fishing and the inherent difficulty to discern between them; but, secondly due to lack of good quality data that can produce robust statistical results. Still, some environmental parameters are well known to affect fish biology. Temperature could influence patterns of maturity, either directly or through changes in growth (Beacham, 1983; Brander, 1995; Cardinale and Modin, 1999). The onset of maturation requires that certain conditions are fulfilled at a specific times in the life cycle, either with respect to size or accumulations of energy stores, or both, thus growth is considered a prerequisite for maturation Saborido-Rey and Kjesbu, in press).

Size and age at maturity are highly plastic parameters that change under external pressure, particularly with a decrease in the population abundance (Adams, 1980; Gunderson, 1980; Wootton, 1990). Shifts in age at maturity have been more often identified as a density-dependent response to abundance variations, mostly decreasing maturity with declining abundance (Beacham, 1983; Cardinale and Modin, 1999; Hutchings, 2004; Jørgensen, 1990; Morgan and Brattey, 1996; Saborido-Rey and Junquera, 1998, 1999). However, although decreasing size at maturity still can be a density-dependence effect, it normally provides an indicator that a fish population is coming under stress from too high rates of exploitation (Trippel, 1995). Barot et al. (2004) used reaction-norms to identify a downward shift in maturation at size in Georges Bank and Gulf of Maine stocks of Atlantic cod (Gadus morhua) supporting the hypothesis that an evolutionary trend, probably caused by high fishing mortalities, is partially responsible for the observed decrease in age and size at maturation in these cod stocks (Olsen et al., 2005). Regardless the causes of maturation variation, this population characteristic can have large effects on the reproductive output of a stock. For example, shifts to maturation at smaller sizes and younger ages affect fecundity (Rijnsdorp 1991, Kraus et al. 2002, Marteinsdottir and Begg 2002), egg and larval size and viability (Trippel et al., 1997).

The Atlantic population of European hake (Merluccius merluccius) Atlantic population supports a major fishery (Casey and Pereiro, 1995). Currently the existence of two stocks is recognized, the so-called Northern and the Southern stocks (ICES Divisions VIIIc and IXa) (ICES, 2005). Both stocks are outside safe biological limits and EU has developed recovery plans that for the Northern stock being implemented in 2004. Current assessment procedures use a a fixed maturity ogives for both sexes combined for the whole time series in the Northern stock, and annual maturity ogives for both sexes combined for the Southern stock. Both are based on macroscopic observations.

In this paper, we have estimated the annual female maturity ogives for Bay of Biscay (Northern stock) and Galician Coast and Cantabric Sea (Southern stock); which form part of the distribution of the Northern and Southern stock, respectively. We have investigated different number of factors that could affect trends in size at maturity, broadly grouped into: 
stock characteristics, fishing pattern and environmental factors. Specifically, the following factors were utilized: total biomass, total SSB, female only SSB, age diversity index, fishing mortality at age, NAO winter index, upwelling index and temperatures.

\section{Material and methods}

\subsection{Biological data}

The sampling of hake gonads was carried out in two different areas, namely Bay of Biscay (ICES Divisions VIIIabd) and Galician Coast (ICES Division IXa) in the north and northwest Spain.

Maturity data for the Galician coast was available for the years 1980 to 2004 from both spring and autumn surveys (although the same survey was not available every year) and from landing samplings (usually monthly sampling, but all months were not necessarily covered in all years). In the case of Bay of Biscay, maturity data was collected over the periods 19871990, 1996-2004, but always based on port sampling or directly collected by observers on commercial vessels. Maturity was assessed based in macroscopic observations (Table 1). The fact that the data come from very different sources (surveys, landings, observers onboard, as well from different months) created complexity in the data matrix, which was checked and revised to harmonize differences. In 2003 and 2004 maturity ogives were additionally based on histological observations and compared with the macroscopic ogives for the same years (Dominguez et al., 2005). The comparison showed than in a number of cases postspawning fish had been staged as immature. Because the proportion of postspawning/resting fish is higher in autumn, special care was taken when revising the data for those particular months. Unusually high numbers of large immature fish or an unusually large number of postspawning small fish were found in a few hauls. This type of clear inconsistency leads to the removal of the whole haul/sampling/day. Data for 1981 and 1987 in Galician coast were very limited ( 2 and 34 specimens). For these years an average of the size at maturiy of females in the preceding and subsequent years was used. The estimates were derived from 13,840 and 16,702 individuals for Galician coast and Bay of Biscay respectively (Table 2).

Abundance at age was obtained from the data compiled by the ICES Working Group on the Assessment of Hake, Monk and Megrim (ICES, 2006). Female numbers at age were derived by applying the sex-ratios to the Working Group numbers-at-age estimates. Sex-ratios for the Bay of Biscay were available for the period 1987-1994 and 1998-2004, from extensive annual market sampling carried out in the Basque Country fishing harbors. This sampling covered the main fishing fleets targeting European hake in ICES Divisions VIIIabd and Sub-area VII. In addition to the market sampling over the period 1998-2004, samples obtained from observers onboard commercial fishing vessels within two EU projects, "Biological Studies of Demersal Fish: megrim, hake and anglerfish" (BIOSDEF) and "New assessment and biology of the main commercial fish species: Hake and anglerfishes of the Southern shelf demersal stocks in the South of the western Europe" (DEMASSES), were also used to estimate female sex-ratios. The current analysis extended back to 1980, therefore, a 3-year average of the closest years (1987-90) was used to extend sex ratios back to this year. For the period of 1995-1997, where sex-ratio data were not available, the mean of the closest three years was used. Sex-ratios for Galician coast were not available and Bay of Biscay data was used for this area. SSB and females only SSB were estimated from mean weight at age in the catch (as 
used by the Working Group) and the two abundance data sets described above, together with the maturity ogives specifically estimated for this analysis.

The age diversity of the spawning stock was estimated using the Shannon diversity index (Marteinsdottir and Thorarinsson 1998):

$$
H=\left(n \log (n)-\sum_{i=1}^{k} f_{i} \log \left(f_{i}\right) / n\right.
$$

The logarithmic base of 10 was used to compute $H$, where $k$ is the number of age groups, $n$ is the total number of mature fish in all age groups, and $f_{i}$ is the number of mature fish in each age group. Unlike biomass and SSB, this diversity index is relatively independent of stock size as it is estimated from both the number of cohorts contributing to spawning biomass and relative abundance of each age class comprising SSB.

Fishing mortality was obtained from the ICES Working Group VPA estimates (ICES 2005). Mortalities from ages 1 to 7 were selected, since those covered more than $97 \%$ of the population abundance. Data from 1980 to 2004 were used.

\subsection{Environmental data}

Temperatures for the Bay of Biscay are sea surface temperatures, estimated as a mean for the whole year, for the period 1982 to 2004. Temperatures for the Galician Shelf were obtained from monthly CTD transects and hence estimated by $50 \mathrm{~m}$ depth intervals from the sea surface to $300 \mathrm{~m}$. However, temperature in this area was only available for the period 1986 to 2000.

Annual upwelling indexes were estimated from geostrophic winds and Qx as the average of the values from March to July for the period 1982-2004. However, for the Galician Shelf monthly data of temperature and upwelling was available. In order to assess trends in these environmental factors, temperature and upwelling (expressed as -Qx) data were interpolated to create a 3D mesh plot using inverse distance as the smoother and month and year as the X,Y variables. An upwelling index was available for 1965 to 2004.

North Atlantic Oscillation (NAO) data were obtained from NOAA. Only winter NAO was used, as the mean of the January to March values. To compare with trends in the reproductive potential of the stock (SRP), besides mean winter NAO, standardized winter NAO was produced as 3, 5 and 10 year running means.

\subsection{Analysis and modeling caveats}

Maturity ogives were adjusted to a logistic curve as described by Ashton (1972):

$$
\hat{P}=\frac{e^{a+b L}}{1+e^{a+b L}}
$$

and the logit transformation:

$$
\ln \frac{\hat{P}}{1-\hat{P}}=a+b L
$$


where $\hat{P}$ is the predicted mature proportion, a and b the estimated coefficients of the logistic equation and $L$ the length.

The maximum-likelihood method was considered to be the most satisfactory methodology for estimating length and age at maturity (Welch and Foucher, 1988; Hosmer and Lemeshow, 1989). Error variances across the range of the $x$ variable were checked and found to be equal. The goodness-of-fit was assessed using a chi-square test for maximum likelihood. Size and age at maturity were estimated as the minus ratio of the coefficients $(-\mathrm{a} / \mathrm{b})$ by substituting $\hat{P}=0.5$ in Equation (2).

To study the influence of the different fisheries, biological and environmental variables on size at maturity a set of forward stepwise multiple linear regressions were performed; $F$ to enter was fixed to 1.00 and $\mathrm{F}$ to remove fixed to 0.99 , and tolerance at 0.0001 . The $\mathrm{r}^{2}$ and the ANOVA of the relationship between the dependent variable and the selected set in independent variables were used to assess the overall goodness of fit. However, the correlation between the observed and the predicted size at maturity was also used as a good indicator of the prediction power of the model.

Statistica for Windows 6.1 (StatSoft, Inc., 2004) was used to fit both the logistic and the multiple linear regression models, as well as to estimate the correlations.

For both stocks the data used was limited to a reduced area compared with the theoretical distribution of the stock. Northern European hake stocks is distributed through ICES Division IIIa, Subareas II, IV, VI and VII and Divisions VIIIa,b,d, from Bay of Biscay to Norway. However, the data used in this modeling exercise was limited to a reduced part of the distribution of the Northern stock (Bay of Biscay with a northern limit at $48^{\circ} \mathrm{N}$ and a Southern limit of the Basque Coast). The Southern stock, which is distributed from the Cantabrian Sea to Morocco, data was limited to the Galician shelf. Therefore, the results cannot be extrapolated to the whole stock and should be treated with caution. In addition, a number of assumptions have been made in relation to missing data or the way data was compiled, which further underline the need for caution in the interpretation of the results and conclusions. In particular, spatial analyses have not been conducted, and shifts in spatial distribution of hake and/or changes on fishing pattern may affect the estimation of size at maturity, as well as many other stock parameters.

\section{Results and discussion}

\subsection{Maturity ogives}

Size at maturity for each analyzed year and both stocks are given in Fig. 1. For the Southern Stock, with the longer time series, size at maturity declined from $55 \mathrm{~cm}$ in 1980 to $39.5 \mathrm{~cm}$ in 1988, the lowest value observed. Since then, size at maturity progressively increased to the largest value of $53 \mathrm{~cm}$ in 1998. In recent years, size at maturity of southern hake has been stable at around $46.5 \mathrm{~cm}$. Thus, for this particular stock, three different periods can be identified; from 1980 to 1989 with a progressive decline in size at maturity; from 1989 to 1998 with a steady increase and finally from 1999 to the present a stable size at maturity. 
The results suggest that the size at maturity in the Southern Stock declined $16 \mathrm{~cm}$ in 9 years, and increased $14 \mathrm{~cm}$ over another 10 years. Moreover, in the two year period from 1998to 2000 size at maturity declined by $7 \mathrm{~cm}$.

The number of years for which data are available for the Bay of Biscay is much more restricted (Fig. 1). Observed as a whole, there has been a progressive decline in size at maturityh from 1987 to 2004 . Only 1990, 2000 and 2001 break this decreasing trend. The decline in size at maturity in the Bay of Biscay from 1987 to 2004 was of $15 \mathrm{~cm}$ (56 to 41 $\mathrm{cm}$ ), but from 51.6 to $41.4 \mathrm{~cm}$ in 1996-2004, i.e. $10 \mathrm{~cm}$ in 9 years.

Both stocks have undergone different temporal variation in size at maturity. The Southern stock size at maturity decreased notably during the 80 's, and then it increased at similar rate during the 1990s, and finally remained stable in recent years. On the contrary, Bay of Biscay hake showed a higher size at maturity in early years with a decrease through 1990s, then showing a further decrease in recent years. In 2000 and 2001 both maturity ogives were similar and not statistically different. However, in 2003 and 2004 the ogives were statistically different. This suggests that both stocks have responded differently to fluctuating situations, supporting the identity of two different stocks. Currently, ICES consider both as management units based on two main criteria; the first is the presence of a geographical barrier, Cape Breton Canyon, which separates Spanish waters from France in the extreme corner of the Bay of Biscay (ICES, 2006). The second reason is the observation of two spawning areas, one located from the French coast to the Celtic Sea and the other located on the northwest coast of the Iberian Peninsula. However, some controversy exists about the stock structure of European hake in the Atlantic. Some authors consider that there is no separation between traditional Northern and Southern stock because of intense gene flow related to the current systems of this area (Balado et al., 2003) Recent studies based on genetic and biological parameters and incidence of identified parasites used as tags for stock identification suggest that only one stock is really differentiated in the North-east Atlantic; although probably two sub-populations exist and are separated by the Cape Breton Canyon (Lo Brutto et al., 2004; Mattiucci et al., 2004; Castillo et al., 2005). These results are relevant for management purpose and the boundary between these stocks should be reconsidered based on biological evidence.

Estimated total biomass, based on the Working Group figures is much greater in Bay of Biscay than in Southern Stock (Fig. 2a). Nevertheless, both have shown a progressive decline in biomass since the early 1980s to early 1990s. Since then the Northern Stock has shown signs of recovery, whereas the Southern Stock declined progressively until 2001.In 2004 an increase in biomass was observed as consequence of recruitment, but this result. should be considered as preliminary until the high recruitment is confirmed by further data. SSB based on females only and using the maturity ogives estimated in the project (see previous section) showed a similar trend (Fig. 2b). Both stocks underwent a sharp decrease in SSB in the 1980s, earlier in the case of Southern Stock. In 1994, the Northern Stock SSB reached its lowest value, but has shown a slow recovery since then. The Southern stock reached the minimum recorded spawning biomass in 1998, but no recovery has been observed and SSB remains at a low level.. Recruitment in Northern hake, based in Working Group estimates at age 0, did not show any major variations up to 1990 (with an average of 200-250 millions of recruits) then showed a period of higher recruitment up to 1995, decreasing thereafter up to 2000 (Fig. 2c). In recent years, except for 2002, recruitment was lower, at around 160 millions. The trend in Southern stock is quite different. Recruitment dropped from 100 millions in 1986 to 40 millions in 1991, reaching a new low value, 30 millions, in 2000 (Fig. 2c). In recent years, 
however, strong year classes seem to have occurred. In both stocks recruitment in 2004 has been estimated at extremely high values (600 and 132 millions for north and south stock respectively). The Working Group has considered these figures to be unrealistic, and awaits better estimates, thus it has not been considered in the current analyses.

On the Galician shelf, recruitment was positively and significantly correlated with the size at maturity two and one year earlier $\left(r^{2}=0.87\right.$ and 0.61 respectively) in the period 1980-1990. However, for the period between 1990 and 1998, when size at maturity increased, recruitment was significantly, but negatively correlated with size at maturity two years earlier $\left(r^{2}=0.61\right)$. Similarly, the relationships between SSB and size at maturity showed the same trend separately for each period. During the 1980s the decrease in biomass may explain the decline in size at maturity, as reduced biomass may favor accelerated growth as a compensatory response. Reduced size at maturity during the 1980s was not, however, enough to compensate for the lost biomass, and SSB continued decreasing in the 1990s in spite of increasing size at maturity and hence so did recruitment.

Changes in maturity ogives have been recorded by several authors in different species. Haug and Tjemsland (1986) studied Atlantic halibut from Norwegian waters and observed that while age at maturity decreased, size at maturity remained more or less constant. Junquera et al. (1999) described similar results for size at maturity of Greenland halibut from the Northwest Atlantic, and suggest that this species is relatively resilient to environmental changes, and that its reproductive parameters remain stable despite unfavourable conditions, although age at maturity was not considered in their study. Engelhard and Heino (2004a) observed in Norwegian herring that during a collapse of the population, age at maturity diminished, whereas size at maturity increased slightly, probably as a compensatory response. Marteinsdottir and Begg (2002) described for Atlantic cod a decrease in size and age at maturity, not only between years due to overexploitation, but also between Northern and Southern stocks, probably as a consequence of changes in temperature.

\subsection{Changes in maturity in response to fishing pressure}

Fishing mortality at age showed notable differences between stocks, but also among ages within the studied period (Fig. 3). Age 1 in the Southern Stock showed relative high levels of mortality before 1990, but reduced levels since then. In contrast, the Northern Stock showed the highest levels at this age during 1990-1997. At ages 2-4 (Fig. 3) fishing mortality was constant during the whole period for Northern Stock $(\mathrm{F}=0.25)$. For the same ages, in the Southern Stock two different periods can be identified, from 1982 to 1994 with a mean F of 0.4 , and since 1995 to the present with a mean F of 0.6. For both periods fishing mortalities have been considerably higher in Southern Stock compared with Northern Stock. Ages 5-7 (Fig. 3) in Northern Stock showed the highest F values during the period 1988-1996, with a mean F of 0.6, over the rest of the period the mean was 0.3. Only for the period 1989-1992, was the fishing mortality of the Southern Stock lower than that of the Northern Stock. The difference is especially marked in the decade 1992 to 2002, when the Southern stock reached the highest $\mathrm{F}$ estimated in 1995 with a fishing mortality of 1.

Age diversity of the female only SSB based on the Shannon diversity index, was used as proxy for stock structure, and hence the consequences of fishing mortality. In Fig. 4 the diversity index for both stocks since 1982 to 2004 is presented. With the exception of 1982, age diversity was higher in Southern Stock. Age diversity fluctuated from 1982 to 1990 in Northern Stock, but has been at the same level since then with a value of 0.68 . There was 
evidence of an increasing trend in recent years, at the same time that size at maturity decreased steadily. In this period the variables were negatively correlated ( $\mathrm{r}=0.96)$, although the time series of maturity ogives is too short to draw conclusions; for the whole available time series the correlation dropped to 0.76. Age diversity in Southern stock fluctuated across the whole period. However, particular time periods can be distinguished. Between 1982 and 1990, age diversity increased progressively from 0.75 to 0.87 . During the period of decreasing size at maturity (1982-1988), this reproductive parameter was negatively correlated with age diversity $(\mathrm{r}=0.96)$. This result indicates that, in both stocks, a reduction in size at maturity enriched the age diversity of SSB. Increasing age diversity increases the SRP if no other changes in the stock occur (Trippel et al., 1997; Bleil and Oeberst, 2005). The diversity index of the Southern Stock decreased sharply in 1992 and 1993. This was likely a consequence of increasing size at maturity. However, diversity in 1994-1998 was at high levels, in spite of increasing size at maturity. During this period fishing mortality-at-age was particularly high, especially at older ages, with the exception of age 1 (Fig. 3). Although increasing size at maturity will reduce the number of year classes in the SSB, reducing the diversity index, the reduction of abundance at all ages increased the diversity index. Thus, this index alone is not a good proxy for the reproductive potential of the stock, and changes in it are not explained exclusively by observed changes in size at maturity.

Two stepwise multiple regressions were performed on each hake stock to assess the variation in size at maturity as a function of i) fishing mortality at different ages and the age diversity index; and ii) adding different biomass indexes, i.e. total biomass, SSB and female only SSB. The multiple regression i) conducted for Northern hake indicated that fishing mortality at age 2, 4 and 5 has an impact on size at maturity, although the fit was poor ( $\mathrm{F}=5.53, p=0.020$, multiple $\left.r^{2}=0.65\right)$. Predicted size at maturity, however, correlated significantly with observed values $(\mathrm{p}<0.001)$, with an $\mathrm{r}$ of 0.81 (Fig. 5a). In the case of the Southern stock, multiple regression indicated that fishing mortality or age diversity had no significant impact on size at maturity $\left(\mathrm{F}=3.01, p=0.075\right.$, multiple $\left.\mathrm{r}^{2}=0.25\right)$. Predicted versus observed size at maturity correlated poorly $(\mathrm{p}=0.165)$, with an $\mathrm{r}$ of 0.30 (Fig. 5a).

When biomass indexes were incorporated into the model (ii), prediction improved considerably. For Northern hake, the multiple regression indicated that in addition to fishing mortality at age 2, 4 and 5, as in previous case, total biomass and SSB had a significant impact on size at maturity ( $\mathrm{F}=14.11, p=0.002$, multiple $\left.\mathrm{r}^{2}=0.91\right)$. Predicted sizes at maturity from multiple regression were very close to observed values (Fig. 5b) yielding an $r$ of 0.95 $(\mathrm{p}<0.001)$. In the case of the Southern stock, the three indexes of biomass and the age diversity index were significantly related to size at maturity $(\mathrm{F}=16.37, p<0.0001$, multiple $\left.r^{2}=0.90\right)$. The model outputs correlated well with actual size at maturity, with an $r$ of 0.87 $(\mathrm{p}<0.001)$ (Fig. 5b). Similar observations were made by Marteinsdottir and Thorarinsson (1998) who detected that inclusion of a stock age diversity index in Icelandic cod assessment improved the stock-recruitment relationship, and variation of recruitment explained by the model increased from $15 \%$ to $31 \%$ when age composition was considered. Furthermore, Saborido-Rey et al. (2004) not only analysed effects of including age composition of spawner stock in stock-recruitment models, but also considered sex ratio and presence of skip spawners that directly affected estimates of SSB; it was observed that recruitment predictions improved when these variables were included in the model. Marshall et al. (1998) suggested that survey-based indices of total abundance and reproductive potential should be incorporated into the analytical assessment of stock status to indicate the quantity and quality of old spawners, because models based on SSB-recruitment relationship are not sensitive to the true variation in reproductive potential of the stock. 
The reproductive system of fish reacts to any changes in life conditions, consequently variations in growth and reproduction dynamics of fish populations substantially affects fish production not only quantitatively but also qualitatively (Godø and Haug, 1999; Oven, 2004; Saborido-Rey and Kjesbu, in press). Fishing pressure may act as a stress factor by removing older and larger individuals from the spawning stock and causing changes in age and size at maturity. In this situation, intra-specific competition is diminished and smaller fish have more available food, grow at higher rates and reach maturity at younger ages. Morgan and Brattey (2005) propose two possible explanations; on the one hand, they consider that this may be the response to a stock biomass reduction, and on the other, suggest it could be a genetic response to increased mortality. Stressing factors, like fishing, exert a biased selection of individuals, and if they continue for a long time, can fix genetic changes that are reflected in variations of reaction norm (Jørgensen, 1990; Engelhard and Heino, 2004b; Ernande et al., 2004; Barot et al., 2005). This seems to be the case for Flemish Cap cod whose size and age at maturity have decreased, and show no signs of recovery despite the moratorium on fishing only for cod (Saborido-Rey and Junquera, 1999). Bowering (1989) detected a decrease in size at maturity in witch flounder but an increase of age at maturity; the former could be explained by overexploitation but not the latter. Something similar was observed in striped bass (Morone saxatilis) in coastal Rhode Island waters during 1985-1987, where a decrease in size at maturity was accompanied by a slight increase in age at maturity. In contrast, Catostomus commersoni from acidified lakes exhibited late age and large size at sexual maturity despite declines in population size (Trippel, 1995). Although a certain phenotypic plasticity exists, Helser and Brodziak (1998) emphasize that from determined fishing mortality ( $\mathrm{F}=0.5-0.6)$, a stock compensatory response disappears or is very slow.

All these changes in maturity parameters affect stock reproductive potential, because smaller and younger females have different reproductive attributes than larger and older individuals (Solemdal, 1997; Trippel et al., 1997). Maternal physiological status, spawning experience (recruit or repeat spawners) or food rations during gametogenesis are all known to alter fecundity, egg and larval quality, as well as duration of the spawning season (Hislop et al., 1978; Kjesbu et al., 1991; Trippel, 1999; Marteinsdottir and Begg, 2002). Fecundity and relative fecundity generally increase with body size (Wootton, 1979; Kjesbu et al., 1998). Consequently, at the population level, the annual population fecundity (total egg production) will, in addition to the number of mature fish, depend not only on size (age) structure, but also on fish condition (Marshall et al., 1998). Change in stock structure entails a compensatory response of age/size at maturity because depletion of large fish can be compensated for by an increased egg production by young fish (Trippel, 1995). If this compensatory response does not occur a stock could reach a critical stage. Consequently, to improve fisheries assessment, it is necessary to account for compensatory mechanisms of stocks and the variability of maturation parameters (Domínguez, 2007).

\subsection{Changes in maturity ogives in response to environmental fluctuations}

Reduced population biomass normally as a consequence of high fishing exploitation, usually leads to a reduction in the plastic parameter of age at maturity. In the case of the Southern Stock of hake, size at maturity increased over a long period (1988-1998) in spite of continuously decreasing total biomass, SSB and female SSB. Thus, changes in size at maturity are not the only consequence of reduced SSB. However, in the Northern Stock the trend of size at maturity seems to be related to the trend on SSB, which has slowly, but steadily increased since 1995, although with important fluctuations during this period (Fig. 
2b). Size and age at maturity depends not only on the maturation process by itself but also on growth and survival conditions (Olsen et al., 2004) that seems to be conditioned by population abundance. For example, age at maturity of cod from the Irish Sea diminished when SSB decreased, although growth rates did not change (Armstrong et al., 2004). In similar way, size and age at maturity of American plaice from Northwest Atlantic has decreased since the 1960 s coinciding also with a decrease of SSB, the maturation of cohorts being related to total abundance of the stock over the whole life history of the cohort (Morgan and Colbourne, 1999). However, Rätz and Lloret (2005) suggest that for Greenland cod population density only affects growth of younger age groups. On the contrary, in this study it was observed that for the Southern Stock of hake the reduction in size at maturity has no or little effect on SSB, which did not recover in spite of the dramatic decline in size at maturity which,was probably, at least in part, caused by the impact of fishing mortality on SSB. However, as mentioned, size at maturity increased during the 1990s in spite of declining SSB, which is contrary to compensatory theory. The lack of compensatory response is known as depensation. According to Liermann and Hilborn (2001) four mechanisms of depensation exist: i) reduction of fertilization probability, ii) alterations of group dynamics, iii) environmental influences and iv) saturation of predators. These four mechanisms are responsible for lack of acompensatory response, even if stock density and intraspecific competition decrease. This phenomenon could be the explanation for absence of recovery of the Northern cod after 15 years of moratorium (Shelton and Healey, 1999).

Changes in size at maturity must reflect shifts in growth rate of the different cohorts, and since biomass (abundance) has no or little effect on growth, the hypothesized changes in growth rate must be coupled with environmental factors. This might be supported by the fact that the observed changes in size at maturity occurred over a very short time period. If size at maturity changes as a consequence of growth rates, the results presented here should support a highest growth rate than that traditionally used. This hypothesis has been confirmed by the growth rates resulting from tagging experiments of Northern Stock (Lucio et al., 2000; de Pontual et al., 2003).

Environment may play an important role in these changes, affecting growth rate of different cohorts. Three key oceanographic factors have been analyzed in this study: upwelling, NAO and temperature. The upwelling index fluctuated considerably during the study period in both areas (Fig. 6). In general upwelling was relative weak in 1983-1988 and 1998-2004 in Bay of Biscay, and strong during the central period, i.e. 1989-1997. The pattern in the Galician shelf is not so clear, and years of strong upwelling are followed by years of relative weak upwelling. However, since 1991 the upwelling index has declined. For the particular case of the Galician shelf, monthly values of upwelling allowed the creation of an interpolated smooth mesh plot, where the trend is more easily observed (Fig. 7). Upwelling was very strong in spring and summer during the 1970s and early 1980s. Spring upwelling has declined considerably since then, and today is at a low level. Summer upwelling strength has also progressively declined. NAO winter index (Fig. 8) showed positive values during the whole period except in 1985, 1987, 1996 and 2001 and the highest values occurred during the 1990s. When considering the standardized running mean, however, some interesting trends are observed. Firstly, from 1984 to 1988 there was a decline in NAO index from positive to negative values, from a 3 year running mean. This trend is also observed with 5 and 10 year running means, but smoothed. In 1990 the NAO index increased to positive values, remaining at this level for 4, 7 or 12 years depending on the running mean considered (Fig. 8). After this period NAO was negative again until 2004. In general 1987-1988 showed the lowest values 
after a declining period, which coincides with the lowest size at maturity estimated for Southern Stock.

Mean annual surface temperatures were only available for the Bay of Biscay. These temperatures are not only affected by current systems, upwelling and other factors that may alter the SRP, but are very much affected by solar irradiation, as can be observed for the Galician shelf where monthly and annual patterns were very different from those at greater depths (Fig. 9). This figure indicates that during the summer, temperatures were lower than in winter at all the depths analyzed. During the late 1980s the difference between summer and winter temperature was lower, or in other words, in recent years (up until 2000), winters have been warmer than in previous ones. This warming effect persisted at all depths over temporal series, but was higher at relatively shallower depths, i.e. 50-150 m (Fig. 9). The impact of temperature on fish physiology and behavior has been documented for several species. Many studies have described the effects of sea temperature on fish metabolism (Tyler and Colow, 1985; Solemdal, 1997; Martínez et al., 1999; Harvey, 2005; Stevens et al., 2006), growth rates (Rätz et al., 1999; Dutil et al., 2003), condition (Krohn et al., 1997), reproduction (Fedorov, 1971; Wootton, 1990; Jonsson and Jonsson, 2003; Privalikhin, 2003; Basilone et al., 2006; Coombs et al., 2006) or offspring survivorship (Lambert et al., 2003; O’Brien et al., 2003; Abdoli et al., 2005). Furthermore, water temperature also conditions fish population dynamics (Marshall et al., 2000; Armstrong et al., 2004; Yoneda et al., 2006) and distributions (Louge, 1996; Gordoa et al., 2000; Pájaro et al., 2005).

Stepwise multiple regressions were performed for each hake stock to assess the variation in size at maturity as a function of environmental factors, i.e., NAO and the upwelling index. Temperature was not used, firstly because temperature at different depths was not available for Bay of Biscay and secondly because the time series only covered part of the period for which size at maturity data were available. NAO winter index, the three running means and upwelling index of the same year and from the previous year were included in the model. The multiple regression conducted for the Bay of Biscay indicated that the 5 year NAO running mean and upwelling in the preceding year and 10 year NAO running mean of the same year has a significant correlation with size at maturity $\left(\mathrm{F}=8.33, p<0.005\right.$, multiple $\left.\mathrm{r}^{2}=0.74\right)$. Predicted size at maturity from the multiple regression correlated significantly with observed values $(\mathrm{r}=0.86, \mathrm{p}<0.001$ ) (Fig. 5c). In the case of the Southern Stock, the multiple regression indicated that the 10 year NAO running average and upwelling in the preceding year, and the 5 year NAO running mean, upwelling index and winter NAO of the same year has a significant impact on size at maturity $\left(\mathrm{F}=7.12, p<0.001\right.$, multiple $\left.\mathrm{r}^{2}=0.70\right)$. Predicted versus observed size at maturity correlates less well compared with Northern stock but is still significant $(\mathrm{r}=0.84, \mathrm{p}<0.001)($ Fig. $5 \mathrm{c})$.

Althoug temperature was not used in the multiple regression analysis, it is known that it impacts on age and size at maturity (Armstrong et al., 2004; Drinkwater, 2005), although the responses of fish to this factor varies between species (Cook and Heath, 2005). Rose (2005) suggests that small pelagics respond quickly and strongly to climate changes because of their physiological limits and fast potential growth. Moreover, temperature may influence the fish maturation process indirectly through alterations of ecosystem composition, resource availability or hydrographic conditions (Kell et al., 2005; Orlova et al., 2005; Rätz and Lloret, 2005; Rose, 2005). The upwelling process causes a rise of cold deep water rich in nutrients (Wooster et al., 1976; Fraga, 1981) during summer. The increase in nutrients is translated into higher ecosystem productivity and more available food for hake. In these circumstances, females achieve a better condition for the next spawning season, producing higher quality 
offspring that grow at higher rates which results in a larger length at age, i.e. for the same age at maturity the size will be greater. Similarily, juveniles are able to grow more during summer to get into reproductive condition. This mechanism, in spite of its decrease in recent years, could be strong enough to neutralize the negative effect of SSB decrease on size at maturity in Southern Stock. Nevertheless, Castro et al. (1994) suggest that primary production on Galician Shelf may be carried offshore due to current system generated by the upwelling itself. In any case, it would be advisable to analyze historical trends of age at maturity if possible. Besides local physical conditions, there are large-scale climatic changes that may affect fish (Wells et al., 2006); between these large-scale phenomena is NAO. The NAO index acts as integrator of several environmental factors that can have a synergistic effect on fisheries dynamics. NAO impacts on air temperature, wind and precipitation regime and on large water mass distribution and flow with the subsequent influence that all these factors have on ecosystems (Greene and Pershing, 2000; Köster et al., 2005). For example in Northeastern USA high and low periods of yellowtail flounder recruitment were correlated with extreme values of NAO index (Sullivan et al., 2005) and a decline in abundance of Calanus finmarchicus coincides with decrease in the NAO index (Greene and Pershing, 2000). So, NAO may act indirectly on size at maturity of hake in both stocks. Ottersen et al. (2001) has extensively reviewed the of ecological effects of the NAO, both in aquatic and terrestrial ecosystems.

A second set of multiple regressions were performed with both the environmental data and fishing mortality. Prediction improved with both datasets, although environmental data played the most important role. For the Northern Stock, the multiple regressions indicated that in addition to NAO and the upwelling index as before fishing mortality at age 6 had a significant impact on size at maturity but was less important than oceanographic factors. Predicted versus observed size at maturity (Fig. $5 \mathrm{~d}$ ) yielded a slightly higher correlation $(\mathrm{r}=0.91, \mathrm{p}<0.001)$. In the case of the Southern Stock, in addition to environmental factors, which contributed with highest $F$ values, fishing mortality at ages 1, 2, 6 and 7 were included in the final model as significant variables. The model predicted well the observed size at maturity, with an $r$ of $0.91, \mathrm{p}<0.001$ (Fig. 5d). Impact of fishing mortality on size at maturity has been reported in other species such as cod from Irish and North Sea (Armstrong et al., 2004; Kell et al., 2005), however for Greenland cod no relationship was found between fishing intensity and length at age (Rätz and Lloret, 2005). Fishing activity usually removes larger individuals altering age and length composition of stocks that may result in selection of earlier maturing individuals (Olsen et al., 2004). If it continues for long time it can cause the loss of genetic components (Shelton and Healey, 1999), although genetic changes can be explained by other factors such as, genetic flow between close stocks or selective natural predation (Chouinard et al., 2005). In general, is postulated that fishing pressure may modulate fish stock dynamics over shorttime scales while climatic change would have long-time scale effects (Kell et al., 2005; Poulard and Blanchard, 2005; Rose, 2005).

A complex stock can include several sub-stocks that should be assessed and managed as independent units under the Precautionary Approach (Frank and Brickman, 2000). In the light of the present results on the dynamics of Northern and Southern Stocks of hake in recent years it seems that the European hake probably comprises a single population in North Atlantic but has different sub-populations. This hypothesis is supported by genetic and parasitological studies (Lo Brutto et al., 2004; Mattiucci et al., 2004; Castillo et al., 2005) 


\section{Conclusions}

Size at maturity of the Southern Stock hake declined drastically in a very short period during the 1980s but increased at the same rate over the next 10 years probably indicating that there have been no changes in reaction norm, since genetic changes are not easily reversed (Reznick, 1993; Heino et al., 2002a). However, it is very important not to confuse maturity ogives with reaction norms for age and size at maturation, as they describe different, although linked, features (Heino et al., 2002b). Shifts observed in size at maturity are more likely to be the consequence of changes in growth rate.

Decreasing biomass may explain the decline in size at maturity from 1980 to 1988 . However, total and spawning biomass declined even during the period when size at maturity increased, which is contrary to compensatory theory. Shifts in environmental regime, NAO and upwelling, may have contributed to a decelerated growth during this period that explain the later maturation.

Evolution of size at maturity in Bay of Biscay has followed a different pattern, since a steady decline has been observed throughout the study period.. Shifts in size at maturity are well predicted by fishing mortality and age diversity, but the environment may also have played an important role. However, the low number of data available may affect the results of the multiple regressions.

Finally, it is worth mentioning that the data used in this modeling exercise was limited to a reduced part of the distribution of both the Northern and Southern Stocks and, therefore, the results should be treated with caution. In addition, a number of assumptions have been made in relation to missing data or the way data was compiled, which further underline that caution is required in interpreting the results and conclusions.

\section{Acknowledgements}

The authors wish to thanks Dr. Carmen G. Castro from the Institute of Marine Research, Vigo and Dr. Angel Borja from AZTI Fundazioa, for providing the oceanographic and environmental data, as well their advice on how to use it. This work was financially supported by the European Commission within the RASER project (Q5RS-2002-01825).

\section{References}

Abdoli, A., Pont, D. and Sagnes, P. 2005. Influence of female age, body size and environmental conditions on annual egg production of the bullhead. Journal of Fish Biology 67, 1327-1341.

Adams, P. B., 1980. Life history patterns in marine fishes and their consequences for fisheries management. Fishery Bulletin 78, 1-12.

Anon., 2004. Natural changes affect stocks maybe more than fishing. Fishing News, March 12: 3 .

Armstrong, M.J., Gerritsen, H.D., Allen M., McCurdy, W.J. and Peel, J.A.D. 2004. Variability in maturity and growth in a heavily exploited stock: cod (Gadus morhua L.) in the Irish Sea. ICES Journal of Marine Science 61, 98-112. 
Ashton, W.D. 1972. The logit transformation with special reference to its uses in bioassay. Haffner Publishing Co., INC. New York. 88pp.

Balado, M., Montse, P. and Presa, P. 2003. Influence of marine currents on the gene flow among atlantic populations of Merluccius merluccius. IV Simposio sobre el Margen Ibérico Atlántico. $\mathrm{N}^{\circ} 19$ (2b).

Barot, S., Heino, M., O'Brien, L. Dieckmann, U., 2004. Long-term trend in the maturation reaction norm of two cod stocks. Ecological Applications 14, 1257-1271.

Barot, S., Heino, M., Morgan, M.J. and Dieckmann, U. 2005. Maturation of Newfoundland American plaice (Hippoglossoides platessoides): long-term trends in maturation reaction norms despite low fishing mortality? ICES Journal of Marine. Science 62, 56-64.

Beacham, T. D., 1983. Variability in median size and age at sexual maturity of Atlantic cod (Gadus morhua) on the Scotian shelf in the Northwest Atlantic Ocean. Fisheries Bulletin. 181(2), 303-321.

Basilone, G., Guisande, C., Patti, B., Mazzola, S., Cuttitta, A., Bonanno, A., Vergara, A.R. and Maneiro, I. 2006. Effect of habitat conditions on reproductive of the European anchovy (Engraulis encrasicolus) in the Strait of Sicily. Fisheries and Oceanography 15(4), 271-280.

Bleil, M. and Oeberst, R. 2005. The potential fecundity of cod in the Baltic Sea from 1993 to 1999. Journal of Applied Ichthyology 21, 19-27.

Bowering, W. R. 1989. Witch flounder distribution off Southern Newfoundland, and changes in age, growth and sexual maturity patterns with commercial exploitation. Transactions of the American Fisheries Society 118, 659-669.

Brander, K.M., 1995. The effect of temperature on growth of Atlantic cod (Gadus morhua L.). ICES Journal of Marine Science 52, 1-10.

Casey, J., Pereiro, J., 1995. European hake (M. merluccius) in the North-east Atlantic. In Hake: Fisheries, ecology and markets. Edited by J. Alheit and T. J. Pitcher. Chapman and Hall, London. pp. 125-148.

Castillo, A.G.F., Alvarez, P. and Garcia-Vazquez, E. 2005. Population structure of Merluccius merluccius along the Iberian Peninsula coast. ICES Journal of Marine Science 62, 1699-1704.

Castro, C.G., Pérez, F.F., Alvarez-Salgado, X.A., Rosón, G. and Ríos, A.F. 1994. Hydrographic conditions associated with the relaxation of an upwelling event off the Galician Coast (NW Spain). Journal of Geophysical Research 99(C3), 5135-5147.

Cardinale, M., Modin, J., 1999. Changes in size-at-maturity of Baltic cod (Gadus morhua) during a period of large variations in stock size and environmental conditions. Fisheries Research 41, 282-295.

Chouinard, G.A., Swain, D.P., Hammill, M.O. and Poirier, G.A. 2005. Covariation between grey seal (Halichoerus grypus) abundance and natural mortality of cod (Gadus morhua) in the Southern Gulf of S. mentella. Lawrence. Can J. Fish Aquat Sci 62, 1991-2000.

Cook, R. M., Heath, M. R., 2005. The implications of warming climate for the management of North Sea demersal fisheries. ICES Journal of Marine Science 62, 1322-1326.

Coombs, S.H., Smyth, T.J., Conway, D.V.P., Halliday, N.C., Bernal, M., Stratoudakis, Y. and Alvarez, P. 2006. Spawning season and temperature relationships for sardine (Sardina pilchardus) in the eastern North Atlantic. Journal of Marine Biology Association of the United Kingdom 86, 1245-1252.

de Pontual, H., Bertignac, M., Battaglia, A., Bavouzet, G., Moguedet, P. and Groison, A.L. 2003. A pilot tagging experiment on European hake (Merluccius merluccius): methodology and preliminary results. ICES Journal of Marine Science 60, 1318-1327.

Domínguez, R. 2007. Study of Reproductive Potential of Merluccius merluccius in the Galician Shelf. Doctoral Thesis. University of Vigo (Spain). 253pp.+ xxii 
Domínguez, R., Korta, M., Murua, H., Saborido-Rey, F., Quincoces, I., 2005. Variability in size at maturity of European hake (Merluccius merluccius) at Bay of Biscay and Galician Coast. ICES CM 2005/Session Q 29.

Drinkwater, K.F. 2005. The response of Atlantic cod (Gadus morhua) to future climate change. ICES Journal of Marine Science 62, 1327-1337.

Dutil, J.D., Gauthier, J., Lambert, Y., Fréchet, A. and Chabot, D. 2003. Stock rebuilding and fish bioenergetics: low productivity hypothesis. Canadian Science Advisory Secretariat. Research Document 2003/060. Canada. 39 pp.

Engelhard, G.H. and Heino, M. 2004a. Maturity changes in Norwegian spring spawning herring before, during, and after a major population collapse. Fisheries Research 66(2-3), 299-310.

Engelhard, G.H. and Heino, M. 2004b. Maturity changes in Norwegian spring spawning herring Clupea harengus: compensatory or evolutionary responses? Marine Ecology Progress Series 272, 245-256.

Ernande, B., Dieckmann, U. and Heino, M. 2004. Adaptive changes in harvested populations: plasticity and evolution of age and size at maturation. Proceedings of the Royal Society of London B. 271, 415-423.

Fedorov, K.Y. 1971. The State of the gonads of the Brents Sea Greenland Halibut (Reinhardtius hippoglossoides, Walb.)in connection with failure to spawn. Journal of Ichthyology 11(5), 673-681.

Fraga, F. 1981. Upwelling off the Galician coast, Northwest Spain. In Richards, F.A. (ed.) Coastal upwelling American geophysical Union, Washintong, D.C. 176-182.

Frank, K.T. and Brickman, D. 2000. Allee effects and compensatory population dynamics within a stock complex. Canadian Journal of Fisheries and Aquatic Science 57, 513-517.

Greene, C.H. and Pershing, A.J. 2000. The response of Calanus finmarchicus populations to climate variability in the Northwest Atlantic: basin-scale forcing associated with the North Atlantic Oscillation. ICES Journal of Marine Science 57, 1536-1544.

Godø, O.R. and Haug, T. 1999. Growth rate and sexual maturity in cod (Gadus morhua) and Atlantic halibut (Hippoglossus hippoglossus). Journal of Northwestern Atlantic Fisheries Science 25, 115-123.

Gordoa, A., Masó, M. and Voges, L. 2000. Monthly variability in the catchability of Namibian hake and its relationship with envirnmental seasonality. Fisheries Research 48, 185-195.

Gunderson, D. R., 1980 . Using $r-K$ selection theory to predict natural mortality. Canadian Journal of Fisheries and Aquatic Sciences 37, 2266-2271.

Harvey, C.J. 2005. Effects of El Niño events on energy demand and egg production of rockfish (Scorpaenidae: Sebastes): a bioenergetics approach. Fisheries Bulletin 103(1), 7183.

Haug, T. and Tjemsland, J. 1986. Changes in size and age distribution and age at sexual maturity in Atlantic Halibut, Hippoglossus hippoglossus, caught in North Norwegian waters" Fisheries Research 4(2), 145-155.

Heino, M., Dieckmann, U and Godø, O.R. 2002a Reaction norm analysis of fisheries-induced adaptive change and the case of the Northeast Arctic cod. ICES CM 2005/Session Y 14

Heino, M., Dieckmann, U and Godø, O.R. 2002b Estimating reaction norms for age and size at maturation with reconstructed immature size distributions: a new technique illustrated by application to Northeast Arctic cod. ICES Journal of Marine Science 59, 562-575.

Helser, T.E. and Brodziak, K.T. 1998. Impacts of density-dependent growth and maturation on assessment advice to rebuild depleted U.S. silver hake (Merluccius bilinearis) stocks. Canadian Journal of Fisheries and Aquatic Science 55, 882-892. 
Hilborn R., Walters C.J., 1992. Quantitative fisheries stock assessment: choice, dynamics and uncertainty. Chapman and Hall, New York.

Hislop, J.R.G., Ross, A.P. and Gauld, J.A. 1978. Observations on effects of feeding level on growth and reproduction in haddock, Melanogrammus aeglefinus (L.) in captivity. Journal of Fish Biology 13, 85-98.

Hosmer, D. W., Lemeshow, S., 1989. Applied logistic regression. John Wiley \& Sons, NY, 307pp.

Hutchings, J.A., 2004. Life history consequences of overexploitation to population recovery in Northwest Atlantic cod (Gadus morhua). Canadian Journal of Fisheries and aquatic Science 62, 824-832.

ICES. 2006. Report of the Working Group on the Assessment of Hake, Monk and Megrim (WGHMM). ICES CM 2006/ACFM:01. 878 pp.

Jonsson, N. and Jonsson, B. 2003. Energy allocation among developmental stages, age groups, and types of Atlantic salmon (Salmo salar) spawners. Canadian Journal of Fisheries and Aquatic Sciences 60(5), 506-516.

Jørgensen, T. 1990. Long-term changes in age at sexual maturity of Northeast Arctic cod (Gadus morhua L.). Journal du Conseil International pour l'Exploration de la Mer 46, 235248.

Junquera, S., Roman, E., Paz, X. and Ramilo, G. 1999. Changes in Greenland halibut growth, condition and fecundity in the Northwest Atlantic (Flemish Pass, Flemish Cap and southern Grand Banks). Variations in maturation, growth, condition and spawning stock biomass production in groundfish. Journal of Northwest Atlantic Fishery Science 25, 1728.

Kell, L.T., Pilling, G.M. and O’Brien, C.M. 2005. Implications of the climate change for the management of North Sea cod (Gadus morhua). ICES Journal of Marine Science 62, 14831491.

Kjesbu, O.S., Klungsoyr, J., Kryvi, H., Witthames, P.R. and Greer Walker, M. 1991. Fecundity, atresia and egg size os captive Atlantic cod (Gadus morhua) in relation to proximate body composition. Canadian Journal of Fish and Aquatic Science 48, 23332343.

Kjesbu, O.S., Witthames, P.R., Solemdal, P. and Walker, M.G. 1998. Temporal variations in the fecundity of Arcto-Norwegian cod (Gadus morhua) in response to natural changes in food and temperature. Journal of Sea Research 40(3-4), 303-321.

Köster, F.W., Möllmann, C., Hinrichsen, H.H., Wieland, K., Tomkiewicz, J., Kraus, G., Voss, R., Makarchouk, A., MacKenzie, B.R., St. John, M.A., Schnack, D., Rohlf, N., Linkowski, T. and Beyer, J.E. 2005. Baltic cod recruitment - the impact of climate variability on key processes. ICES Journal of Marine Science 62, 1408-1425.

Kraus, G., Tomkiewicz, J., Köster, F.W., 2002. Egg production of Baltic cod (Gadus morhua) in relation to variable sex ratio, maturity, and fecundity. Canadian Journal of Fisheries and Aquatic Sciences 59, 1908-1920.

Krohn, M., Reidy, S. and Kerr, S. 1997. Bioenergetic analysis of the effects of temperature and prey availability on growth and condition of northern cod (Gadus morhua). Canadian Journal of Fisheries and Aquatic Science 54 (Suppl. 1), 113-121.

Lambert, Y., Yagarina, N.A., Kraus, G., Marteinsdottir, G. and Wright, P.J. 2003. Using environmental and biological indices as proxies for egg and larval production of marine fish. Journal of Northwest Atlantic Fisheries Science 33, 115-159.

Liermann, M. and Hilborn, R. 2001. Depensation: evidence, models and implications. Fish and Fisheries 2, 33-58. 
Lo Brutto, S., Arcuelo, M. and Parrinello, N. 2004. Congruence in genetic markers used to describe Mediterranean and Atlantic populations of European hake (Merluccius merluccius, L. 1758). Journal of Applied Ichthyology 20, 81-86.

Louge, E.B. 1996. Variaciones espacio-temporales del fenómeno reproductivo de la merluza Merluccius hubbsi (Marini, 1933) durante su concentración invernal en la zona común de pesca argentino-uruguaya. Boletin del Instituto Español de Oceanografia 11, 123-139.

Lucio, P., Santurtun, M., and Quincoces, I. 2000. Tagging experiments on hake, anglerfish and other species in the Bay of Biscay. ICES CM 2000/Z: 09.

Marshall, C.T., Kjesbu, O.S., Yagarina, N.A., Solemdal, P. and Ulltang, O. 1998. Is spawner biomass a sensitive measure of the reproductive and recruitment potencial of Northeast Artic cod? Canadian Journal of Fisheries and Aquatic Science 55 (7), 1766-1783.

Marshall, C.T., Yagarina, N.A., Aadlandsvik, B. and Dolgov, A.V. 2000. Reconstructing the stock-recruit relationship for northeast Arctic cod using a bioenergetic index of reproductive potential. Canadian Journal of Fisheries and Aquatic Sciences 57(12), 24332442.

Marteinsdottir, G., Begg, G.A. 2002. Essential relationships incorporating the influence of age, size and condition on variables required for estimation of reproductive potential in Atlantic cod Gadus morhua. Marine Ecology Progress Series 235, 235-256.

Marteinsdottir, G., Thorarinsson, K., 1998. Improving the stock-recruitment relationship in Icelandic cod (Gadus morhua) by including age diversity of spawners. Canadian Journal of Fisheries and Aquatic Sciences 55, 1372-1377.

Martínez, M.; P. Couture and H. Guderley. 1999. Temporal changes in tissue metabolic capacities of wild Atlantic cod Gadus morhua (L.) from Newfoundland. Fish Physiology and Biochemistry. Vol. 20, 181-191.

Mattiucci, S, Abuaunza, P., Ramadori, L. and Nascetti, G. 2004. Genetic identification of Anisakis larvae in European hake from Atlantic and Mediterranean waters for stock recognition. Journal of Fish Biology 65, 495-510.

Morgan, M.J., Brattey, J., 1996. Maturity of female cod in 2J3KL. DFO Atlantic Fisheries, Research Document, 96/64.

Morgan, M.J. and Brattey, J. 2005. Effect of changes in reproductive potential on perceived productivity of three Northwest Atlantic cod (Gadus morhua) stocks. ICES Journal of Marine Science 62, 65-74.

Morgan, M.J. and Colbourne, E.B. 1999. Variation in maturity-at-age and size in the three populations of American plaice. ICES Journal of Marine Science 56, 673-688.

Murua, H., Kraus, G., Saborido-Rey, F., Witthames, P. R., Thorsen, A. Junquera, S., 2003. Procedures to estimate fecundity of marine fish species in relation to their reproductive strategy. Journal of Northwest Atlantic Fishery Science 33, 33-54.

O’Brien, L., Rago, P.J., Berrien, P. and Lough, G. 2003. Incorporating Early-Life History Parameters in the Estimation of the Stock-Recruit Relationship of Georges Bank Atlantic Cod (Gadus morhua). Journal of Northwest Atlantic Fisheries Science 33, 191-205.

Olsen, E.M., Heino, M., Lilly, G.R., Morgan, M.J., Brattey, J., Ernande, B. and Dieckmann, U. 2004. Maturation trends indicative of rapid evolution preceded the collapse of northern cod. Nature 428, 932-935.

Olsen, E.M., Lilly, G.R., Heino, M. Morgan, M.J., Brattey, J., Dieckmann, U., 2005. Assessing changes in age and size at maturation in collapsing populations of Atlantic cod (Gadus morhua). Canadian Journal of Fisheries and Aquatic Sciences 62, 811-823.

Orlova, E.L., Boitsov, V.D., Dolgov, A.V., Rudneva, G.B. and Nesterova, V.N. 2005. The relationship between plankton, capelin and cod under different temperature conditions. ICES Journal of Marine Science 62, 1281-1292. 
Ottersen, G., Planque, B., Belgrano, A., Post, E., Reid, P.C. and Stenseth, N.C. 2001. Ecological effects of the North Atlantic Oscillation. Oecologia 128, 1-14.

Oven, L.S. 2004. Resorption of Vitellogenous Oocytes as an Indicador of the State of the Black Sea Fish Populations and Their Environment. Journal of Ichthyology 44(1), 115119.

Pájaro, M., Macchi, G.J., Martos, P. 2005. Reprodcutive pattern of the Patagonian stock of Argentine hake (Merluccius hubbsi). Fisheries Research 72, 97-108.

Poulard, J.C. and Blanchard, F. 2005. The impact of climate change on the fish community structure of eastern continental shelf of the Bay of Biscay. ICES Journal of Marine Science 62, 1436-1443.

Privalikhin, A.M. 2003. Resorption of Developing Oocytes as a Regulatory Mechanism of Formation of Individual and Population Fecundity in Walleye Pollock Theragra chalcogramma (Gadidae). Journal of Ichthyology 43(6), 454.

Rätz, H.J. and Lloret, J. 2005. Long-term variability of growth and recruitment of cod (Gadus morhua) off Greenland. ICES Journal of Marine Science 62, 1310-1321.

Rätz, H.J., Stein, M. and Lloret, J. 1999. Variation in Growth and Recruitment of Atlanic cod (Gadus morhua) off Greenland during the second half of the Twentieth Centur. Journal of Northwestern Atlantic Fisheries Science 25, 161-170.

Reznick, D.N. 1993. Norms of reaction in fishes. In: Stokes TK, McGlade JM, Law R (eds) The exploitation of evolving resources. Springer-Verlag, Berlin, p 72-90

Rijnsdorp, A.D., 1991. Changes in fecundity of female North Sea plaice (Pleuronectes platessa L.) between three periods since 1900. ICES Journal of Marine Science 48, 253280.

Rose, G.A. 2005. On distributional responses of North Atlantic fish to climate change. ICES Journal of Marine Science 62, 1360-1374.

Saborido Rey, F., Junquera, S., 1998. Histological assessment of the variations in sexual maturity of cod (Gadus morhua) in Flemish Cap (Northwest Atlantic). ICES Journal of Marine Science 55, 515-521

Saborido Rey, F., Junquera, S., 1999. Spawning biomass variation in Atlantic Cod (Gadus morhua) in Flemish Cap in relation to changes in growth and maturation. Journal of Northwest Atlantic Fisheries Science 25, 83-90

Saborido-Rey, F., Morgan, M.J. and Domínguez, R. 2004. Estimation of Reproductive Potential for Felmish Cap Cod. NAFO SCR Doc. 04/61 Serial No N5022, 8pp.

Saborido-Rey, F, Kjesbu, O.S., in press. Growth and maturation dynamics. In: Dieckmann, U., Godø, O.R., Heino, M., Mork, J. (Eds), Fisheries-Induced Adaptive Changes. Cambridge University Press (In press)

Shelton, P.A. and Healey, B.P. 1999. Should depensation be dismissed as a possible explanation for the lack of recovery of the northern cod (Gadus morhua) stock? Canadian Journal of Fisheries and Aquatic Sciences 56, 1521-1524.

Solemdal, P. 1997. Maternal effects - A link between the past and the future. Journal of Sea Research 37(3-4), 213-227.

StatSoft, Inc., 2004. STATISTICA (data analysis software system), version 6. www.statsoft.com. en RASER)., 2

Stevens, J., Maes, J. and Ollevier, F. 2006. A bioenergetics model for juvenile flounder Platichthys flesus. Journal of Applied Ichthyology 22, 79-84.

Sullivan, M.C., Cowen, R.K. and Steves, B.P. 2005. Evidence for atmosphere-ocean forcing of yellowtail flounder (Limanda ferruginea) recruitment in the Middle Atlantic Bight. Fisheries Oceanography 14(5), 386-399.

Trippel, E.A., 1995. Age at maturity as a stress indicator in fisheries. BioScience 45, 759-771. 
Trippel, E.A. 1999. Estimation of stock reproductive potential: history and challenges for Canadian Atlantic gadoid stock assessments. Variations in maturation, growth, condition and spawning stock biomass production in groundfish. Journal of Northwest Atlantic Fishery Science 25, 61-81.

Trippel, E.A., Kjesbu, O.S., Solemdal, P., 1997. Effects of adult age and size structure on reproductive output in marine fishes. In: Chambers, R.C. Trippel, E.A. (eds). Early life history and recruitment in fish populations. Chapman and Hall, London, pp 31-62

Tyler, P. and Colow, P. 1985. Fish energetics. New perspectives. Croom Helm, LondonSydney. 349pp.

Vitale, F., Svedäng, H., Cardinale, M., 2006. Histological analysis invalidates macroscopically determined maturity ogives of the Kattegat cod (Gadus morhua) and suggests new proxies for estimating maturity status of individual fish. ICES Journal of Marine Science 63, 485-492

Welch, D. W., Foucher, R. P., 1988. A maximum likelihood methodology for estimating length-at-maturity with application to Pacific cod (Gadus macrocephalus) population dynamics. Canadian Journal of Fisheries and Aquatic Sciences 45, 333-343.

Wells, B.K., Grimes, C.B., Field, J.C. and Reiss, C.S. 2006. Covariation between the average lengths of mature coho (Oncorhynchus kisutch) and Chinook salmon (O. tshawytscha) and the ocean environment. Fisheries Oceanography 15(1), 67-79.

Wooster, W.S., Bakun, A. and McLain, D.R. 1976. The seasonal upwelling cycle along the eastern boundary of the North Atlantic. Journal of Marine Research 34(2), 131-141.

Wootton, R. J. 1979. Energy costs of egg production and environmental determinants of fecundity in teleost fishes. Symposium of Zoological Society London 44, 133-159.

Wootton, R.J. 1990. Ecology of Teleost Fishes. Fish and Fisheries Series. No.1. Chapman and Hall. 404pp.

Yoneda, M., Yamamoto, K., Yamasaki, S. and Matsuyama, M. 2006. Growth and maturation variability of female John Dory (Zeus faber) in the East China Sea in relation to thermal gradients. Journal of Marine Biology Association UK 86, 885-892. 
Table 1. Macroscopic maturity classification criteria of female European hake

STAGE

Immature

Incipient maturation

Matures

Hydrated

Advanced mature

Spent

Recovering

DESCRIPTION

Ovaries emerge as tiny, paired organs in posterior body cavity; glassy orange-reddish and translucent. No opaque oocytes are observed.

Ovaries still small, opaque, orange to creamy yellow. Oocytes clearly visible.

Ovaries enlarge to mid body cavity, firm, orange to creamy yellow with some blood vessels. Oocytes are clearly visible and densely packed.

Ovaries fill most of body cavity, appear granulated pink to orange-reddish with mixture of opaque and transparent oocytes, prominent blood vessels. Lumen containing viscous fluid or hydrated eggs.

Ovaries enlarge to mid body cavity, plump and flabbier than Matures with prominent blood vessels, opaque, orange to creamy yellow. Oocytes clearly visible and densely packed.

Ovaries shrunk to posterior body cavity, completely flabby with prominent blood vessels, dark red to purple. Opaque oocytes are few or absent.

Ovaries contracted and somewhat uneven walls, slack, blurred translucent orange- to reddish-grey. Opaque oocytes absent, but single hydrated eggs or atretic oocytes (opaque, irregular granules) may occur. 
Table 2.- Number of analyzed fish by year, quarter, area and source of the samples, including the length range and the number of immature and mature fish by year in Galician shelf

\begin{tabular}{|c|c|c|c|c|c|c|c|c|c|c|c|c|c|c|c|c|c|c|}
\hline \multirow[b]{3}{*}{ Year /Quarter } & \multicolumn{11}{|c|}{ Galician shelf } & \multicolumn{7}{|c|}{ Bay of Biscay } \\
\hline & \multicolumn{4}{|c|}{ Research surveys } & \multicolumn{4}{|c|}{ Landing } & \multirow{2}{*}{$\begin{array}{l}\text { Length } \\
\text { range }\end{array}$} & \multirow{2}{*}{$\begin{array}{l}\mathrm{n}^{\circ} \\
\text { immature }\end{array}$} & \multirow{2}{*}{$\begin{array}{l}\mathrm{n}^{\mathrm{o}} \\
\text { mature }\end{array}$} & \multicolumn{4}{|c|}{ Landing } & \multirow{2}{*}{$\begin{array}{l}\text { Length } \\
\text { range }\end{array}$} & \multirow{2}{*}{$\begin{array}{l}\mathrm{n}^{\mathrm{o}} \\
\text { immature }\end{array}$} & \multirow{2}{*}{$\begin{array}{l}\mathrm{n}^{\mathrm{o}} \\
\text { mature }\end{array}$} \\
\hline & 1 & 2 & 3 & 4 & 1 & 2 & 3 & 4 & & & & 1 & 2 & 3 & 4 & & & \\
\hline 1980 & & & & & & 136 & 177 & 38 & $21-66$ & 338 & 13 & & & & & & & \\
\hline 1982 & & & & & 142 & 47 & 31 & & $33-75$ & 61 & 159 & & & & & & & \\
\hline 1983 & & & & & 45 & 104 & & & $23-71$ & 103 & 46 & & & & & & & \\
\hline 1984 & & & & & 278 & 134 & 32 & 95 & $23-77$ & 264 & 275 & & & & & & & \\
\hline 1985 & & & & & 181 & 307 & 258 & 268 & $11-87$ & 628 & 386 & & & & & & & \\
\hline 1986 & & & & & 148 & & 52 & 49 & $25-68$ & 108 & 141 & & & & & & & \\
\hline 1987 & & & & & & & & & & & & & 8 & 56 & 216 & $17-86$ & 241 & 39 \\
\hline 1988 & & & & & 30 & 149 & 270 & & $15-63$ & 369 & 80 & 201 & 365 & 429 & 482 & $10-87$ & 1366 & 111 \\
\hline 1989 & & & & & 153 & 310 & 102 & & $15-70$ & 322 & 243 & 140 & 201 & 333 & 469 & $13-66$ & 1077 & 66 \\
\hline 1990 & 311 & 324 & 226 & 226 & 80 & 76 & 42 & 39 & $14-70$ & 1138 & 186 & 377 & 467 & 279 & 211 & 11-104 & 866 & 468 \\
\hline 1991 & & & 131 & 152 & 52 & 190 & 67 & & $14-65$ & 406 & 186 & & & & & & & \\
\hline 1992 & & & 332 & 164 & 52 & & & & $14-66$ & 528 & 20 & & & & & & & \\
\hline 1993 & & & 58 & & & 107 & & 16 & $16-53$ & 160 & 21 & & & & & & & \\
\hline 1994 & & & 123 & 261 & 81 & 95 & 12 & 85 & $15-78$ & 583 & 74 & & & & & & & \\
\hline 1995 & & & 5 & 289 & 115 & 142 & 57 & 24 & $13-70$ & 526 & 106 & & & & & & & \\
\hline 1996 & & & 155 & 538 & 112 & 169 & 252 & 29 & $14-75$ & 949 & 306 & & 816 & 417 & 650 & $14-91$ & 819 & 1064 \\
\hline 1997 & 69 & 127 & 137 & 185 & 68 & 135 & 75 & 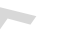 & $10-79$ & 662 & 134 & 813 & 466 & 191 & 145 & $22-92$ & 634 & 981 \\
\hline 1998 & & & 119 & 242 & 34 & 124 & 27 & & $10-68$ & 491 & 55 & 454 & 489 & 139 & 115 & $20-99$ & 536 & 661 \\
\hline 1999 & 24 & & 89 & 232 & 27 & 59 & 2 & & $9-71$ & 369 & 64 & 123 & 103 & & & $21-55$ & 162 & 64 \\
\hline 2000 & 5 & & & 183 & 40 & 53 & 56 & 13 & $10-63$ & 270 & 80 & 199 & 342 & 345 & 360 & $17-59$ & 1160 & 86 \\
\hline 2001 & 14 & 14 & 35 & 183 & 25 & 17 & & & $15-74$ & 260 & 28 & 248 & 1536 & 599 & 68 & 17-101 & 589 & 1862 \\
\hline 2002 & & 145 & 55 & 241 & & 231 & 128 & 38 & $12-75$ & 601 & 237 & 310 & 375 & 532 & 817 & 8-110 & 1535 & 499 \\
\hline 2003 & 52 & 75 & 76 & 146 & 59 & 191 & 201 & 62 & $16-69$ & 691 & 171 & 475 & 224 & 121 & 147 & $32-84$ & 137 & 830 \\
\hline 2004 & 69 & 87 & 92 & 155 & 169 & 198 & 125 & 107 & $15-75$ & 757 & 245 & 275 & 455 & 131 & & $38-87$ & 104 & 757 \\
\hline Total & 544 & 772 & 1633 & 3197 & 1891 & 2974 & 1966 & 863 & & 10584 & 3256 & & & & & & 9220 & 7482 \\
\hline
\end{tabular}




\section{Figure captions}

Fig. 1. Female size at maturity for Northern and Southern Stocks of hake

Fig. 2. Total biomass, female SSB and recruitment for Northern and Southern Stocks of hake.

Fig. 3. Fishing mortality at a) age 1; b) $F_{\text {med }}$ for ages 2-4; and c) $F_{m e d}$ for ages 5-7 for Northern and Southern Stocks of hake.

Fig. 4. Age diversity index for both hake stocks

Fig. 5. Size at maturity against predicted size at maturity from multiple linear regressions for each stock. Multiple regression were performed including in the initial model a) the fishing mortality at age ( 1 to 7$)$, the $F_{\text {med }}$ and the age diversity index; $b$ ) the variables used in previous panel together with the total biomass, SSB and the female SSB; c) the environmental data (Upwelling and Non-standarized and Standarized 3- 5- 10- years running mean winter NAO index and the same indexes lagged one year); and d) the environmental data as in previous panel together with fishing mortality at age 1 to 7 , the $\mathrm{F}_{\text {med }}$ and the age diversity index.

Fig. 6. Annual upwelling index $\left(\mathrm{m}^{3} \mathrm{~s}^{-1} \mathrm{~km}^{-1}\right.$ coast $)$ for the sampling area of both stocks.

Fig. 7. Upwelling index $\left(\mathrm{m}^{3} \mathrm{~s}^{-1} \mathrm{~km}^{-1}\right.$ coast $)$ by month and year in the Galician waters (sampling area of the Southern stock)

Fig. 8. Non-standarized and Standarized 3- 5- 10- years running mean winter NAO index (mbar)

Fig. 9. 3D Mesh plot of the mean monthly temperatures by depth range in Galician shelf. Note the different Z-scale for the surface plot. 


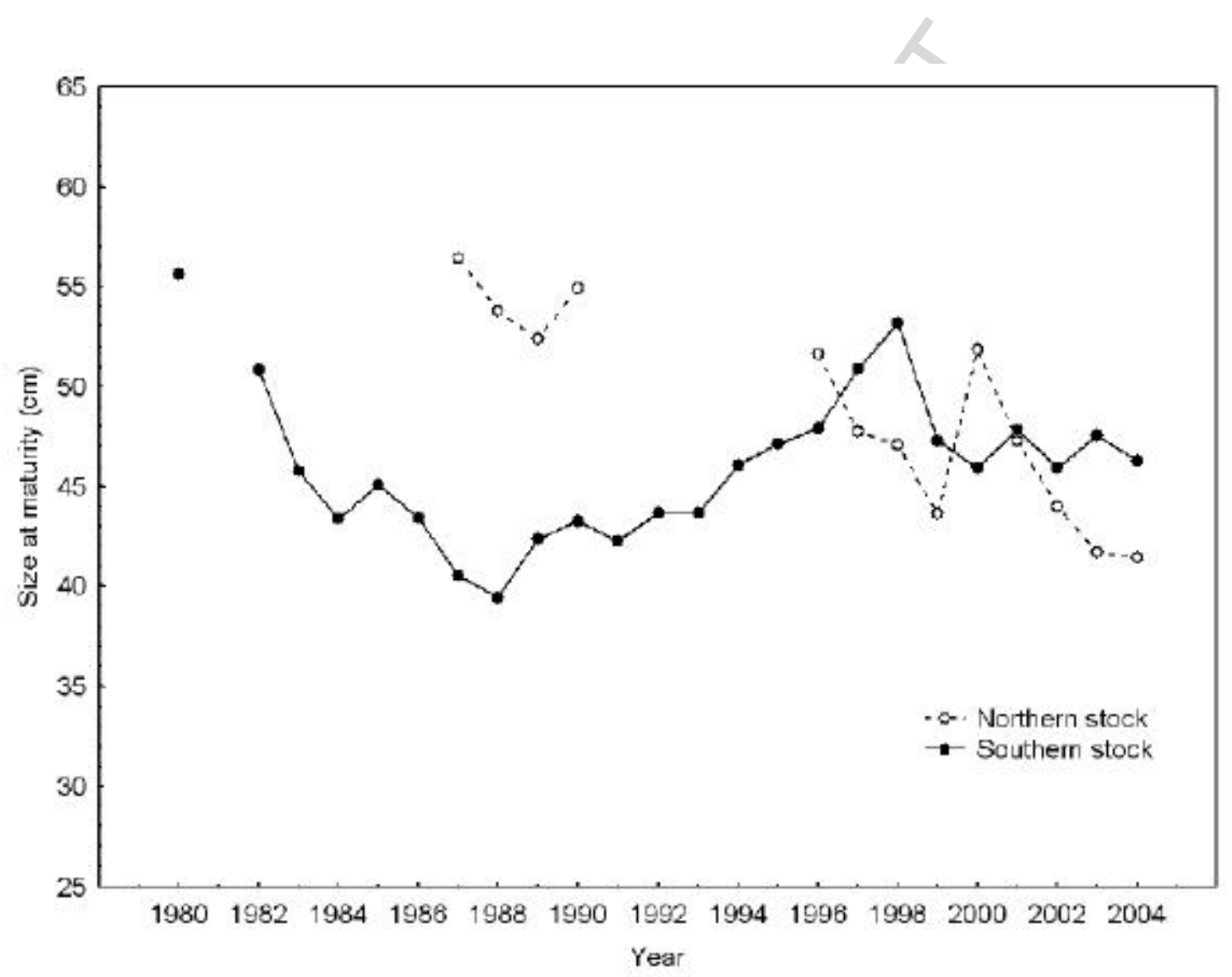



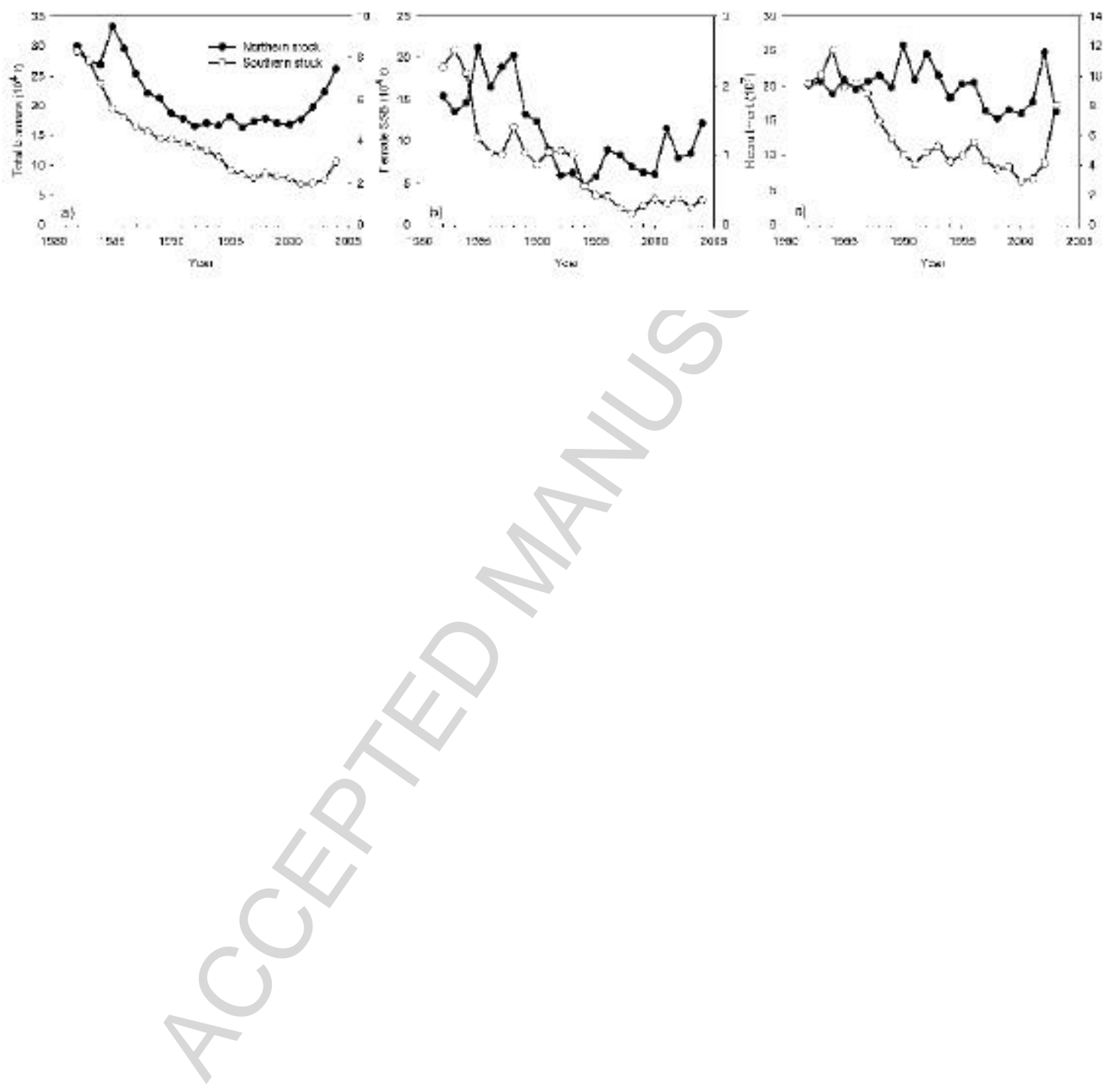

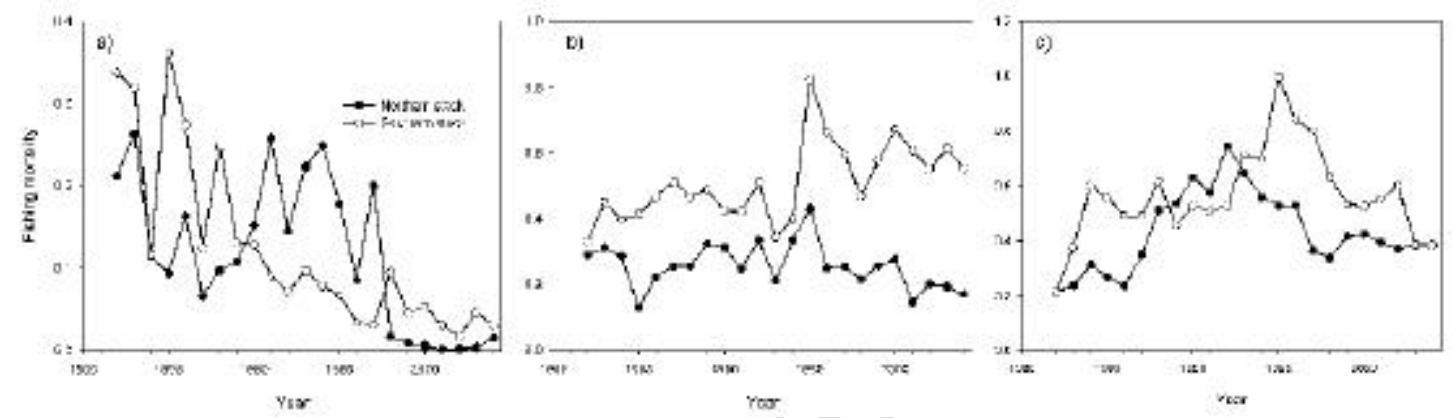


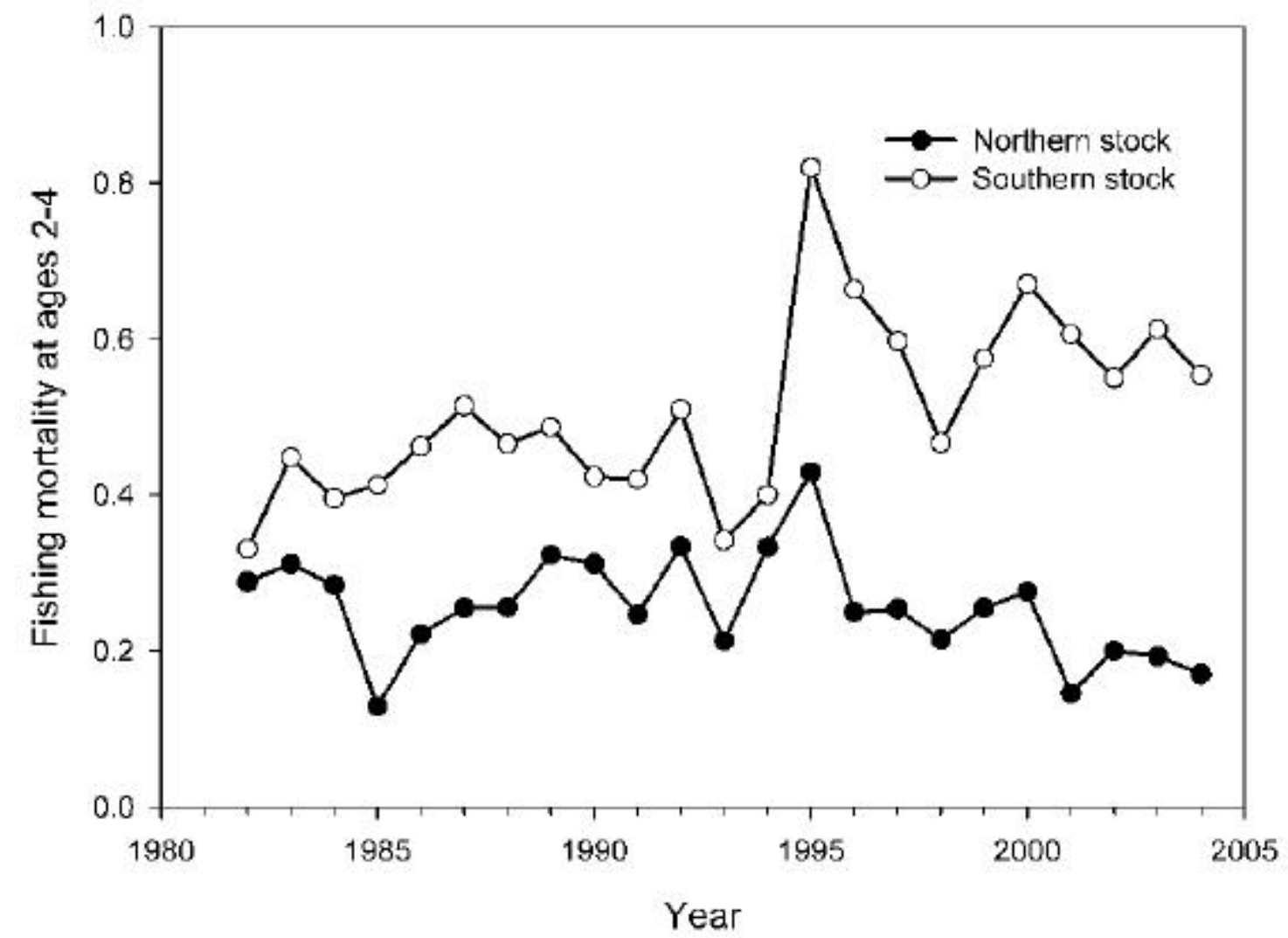



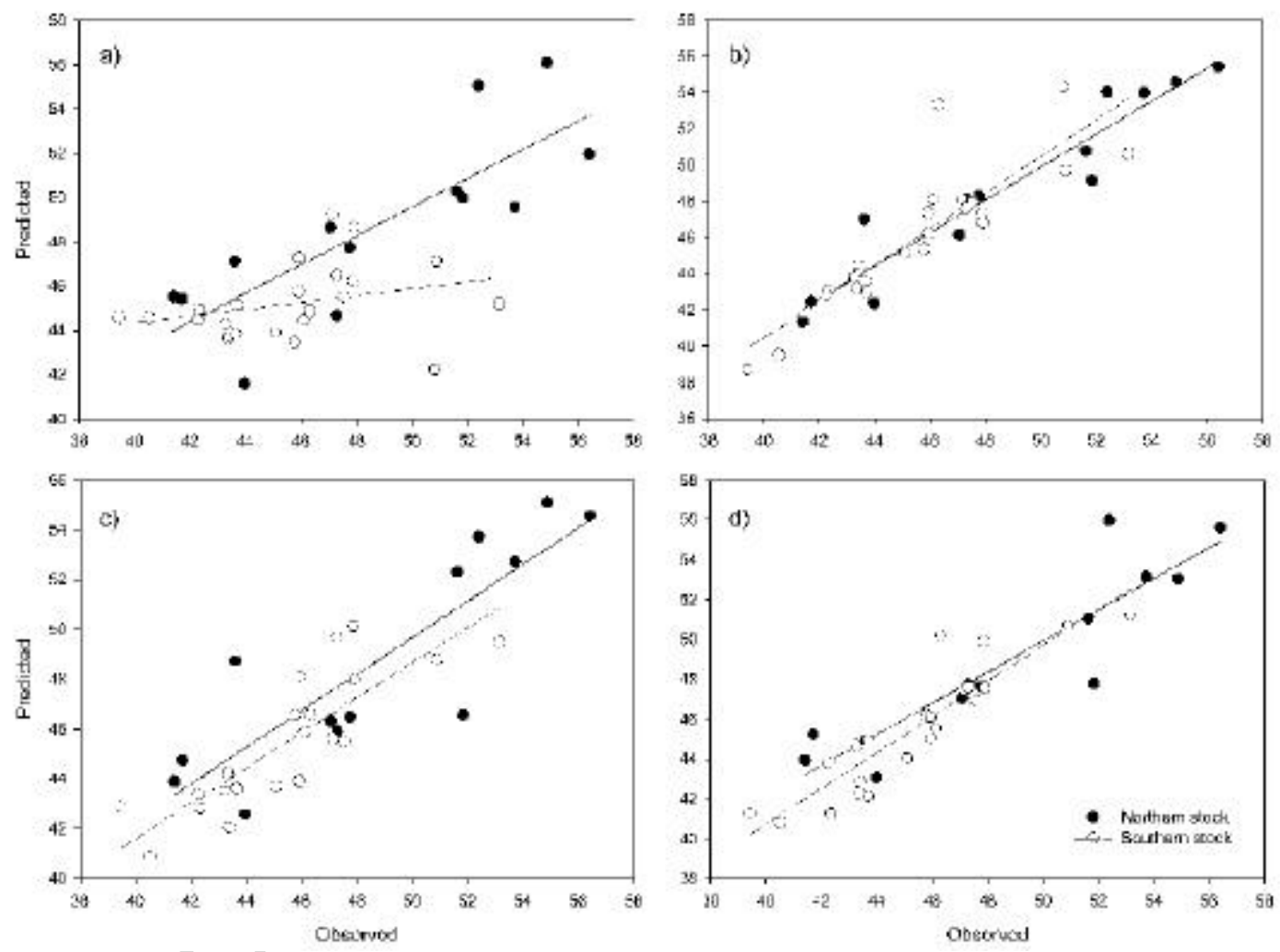


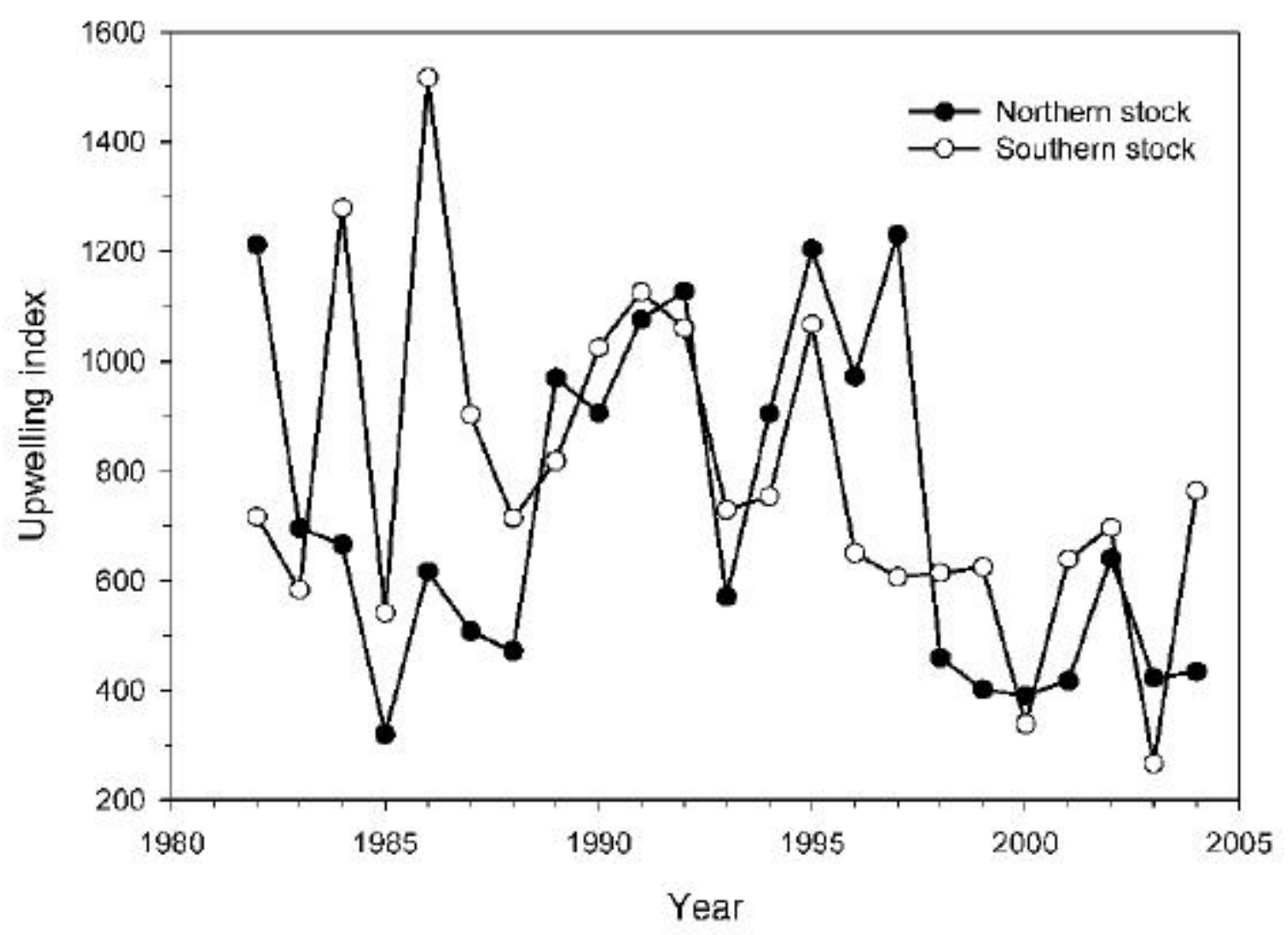




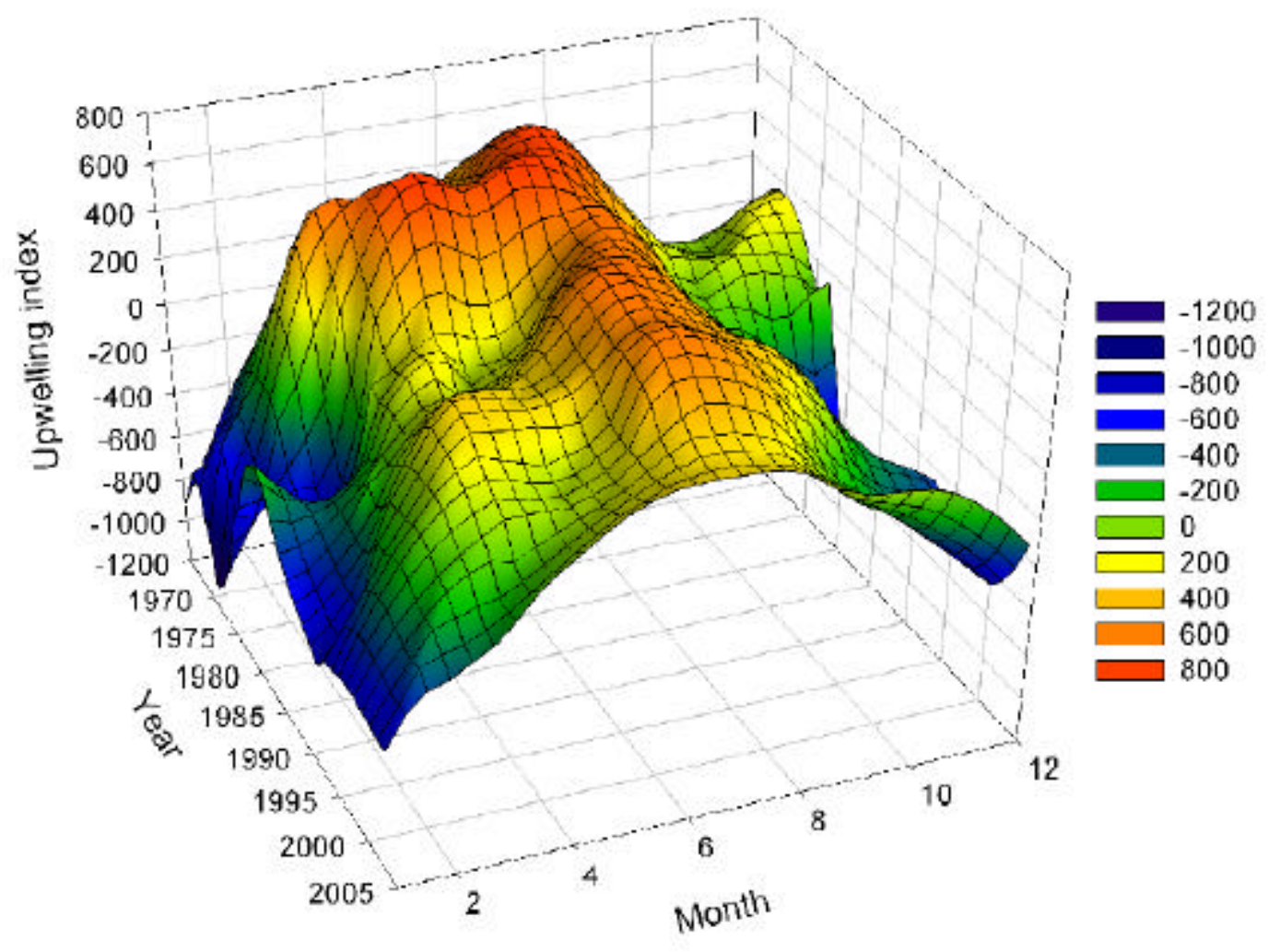




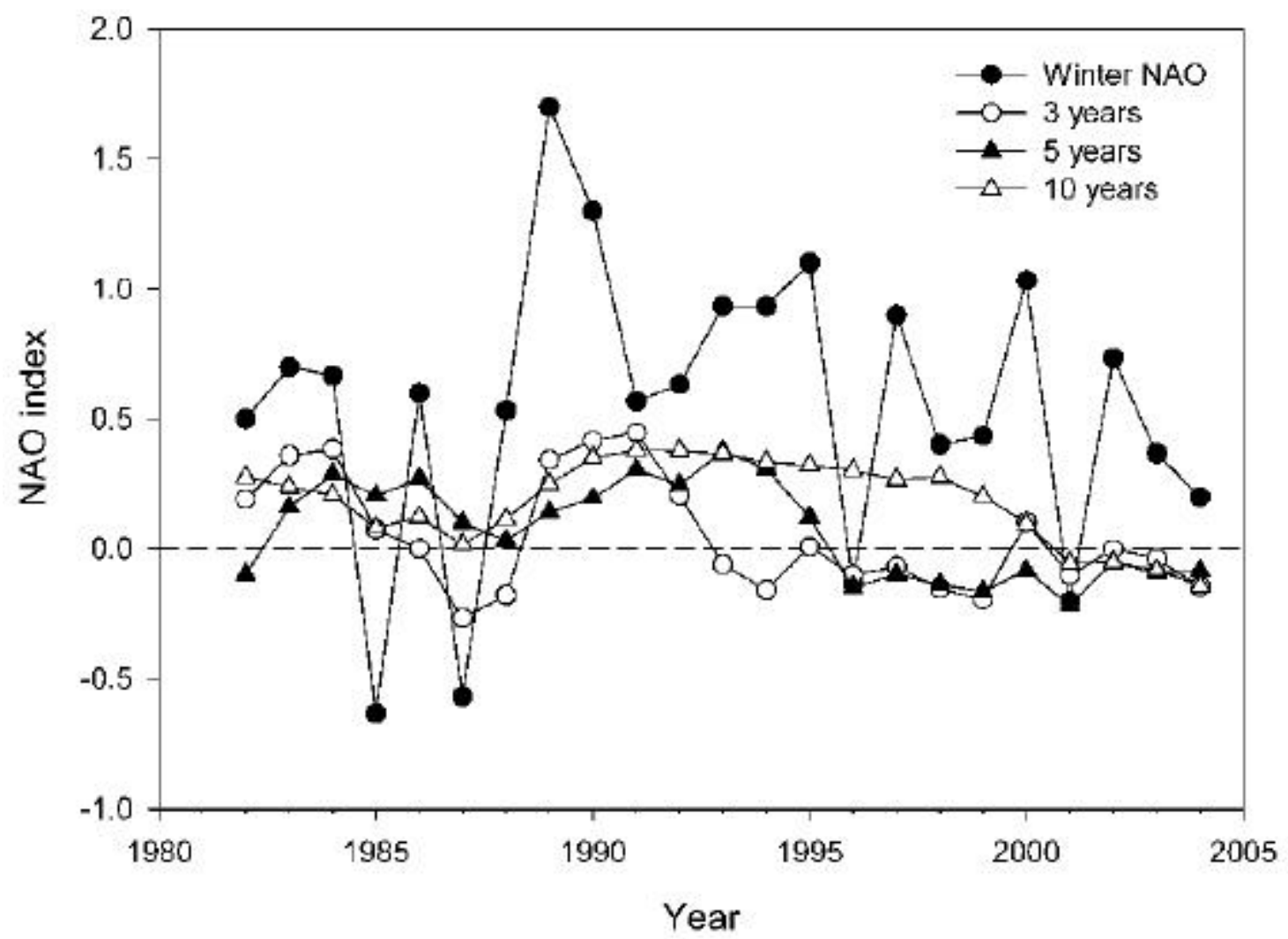



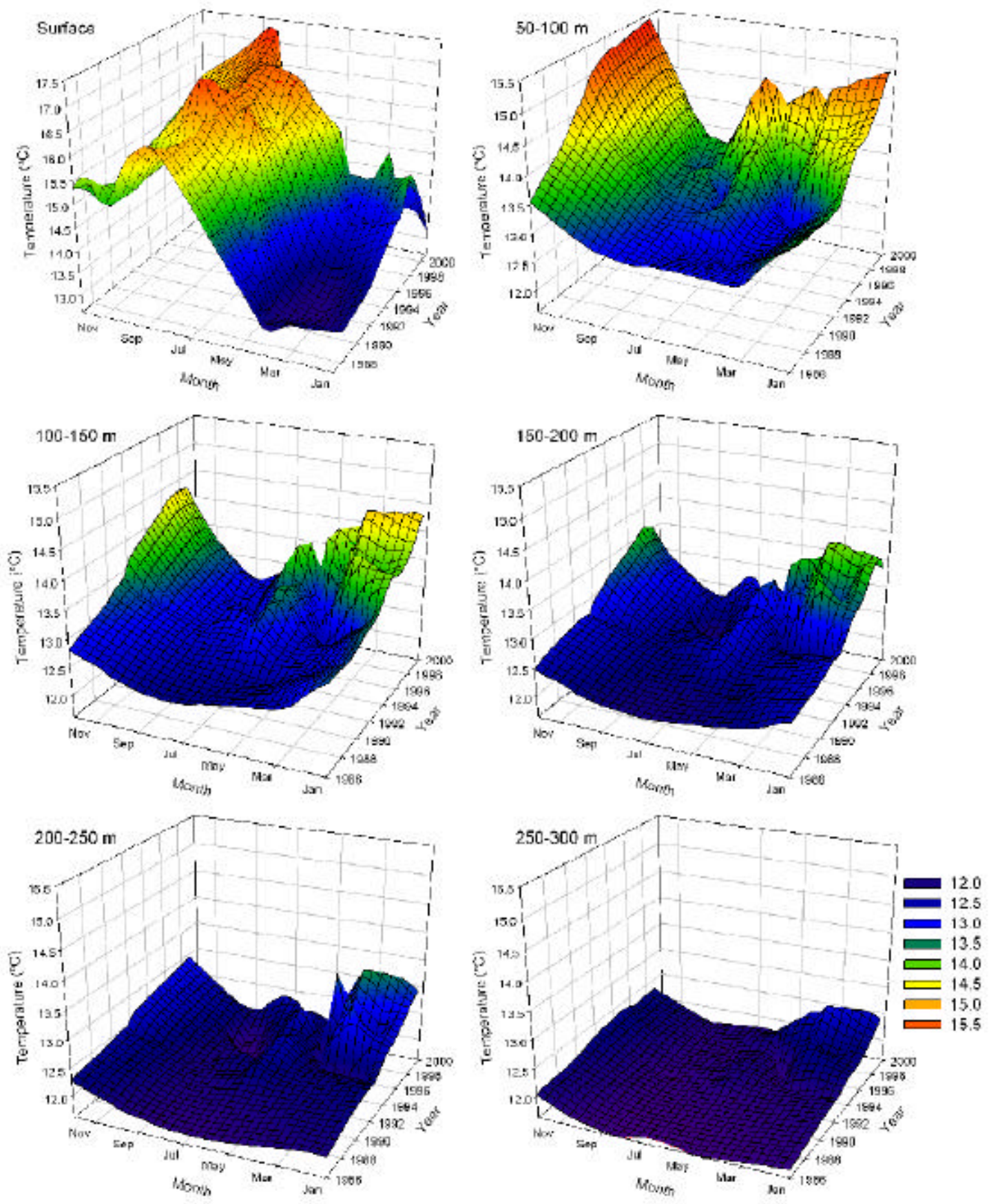